\title{
PELUANG WIRAUSAHA BARU DALAM KREATIVITAS MENGGUNTING BERANTAI DI TAMAN KANAK ANUGRAH SAYANG IBU DI KAMPUANG JUA KECAMATAN SUNGAI LIMAU
}

\author{
Farida Mayar $^{1 *}$, Dadan Suryana ${ }^{2 *}$, Eko Purnomo $^{3 *}$, M. Nasrul Kamal ${ }^{4 *}$ \\ Jurusan Guru Pendidikan Anak Usia Dinil dan 2* \\ Fakultas Ilmu Pendidikan \\ Jurusan Seni Rupa ${ }^{3}$ dan 4* \\ Fakultas Bahasa dan Seni \\ Universitas Negeri Padang \\ Jl. Prof. Dr. Hamta, Air Tawar Padang, Kel. Air Tawar Barat, Kec. Padang Utara, Kota Padang, Kode Pos 25171 \\ Sumatera Barat. Indonesia \\ Email: mayarfarida@gmail.com
}

\begin{abstract}
Abstrak
Pengabdian ini bertujuan untuk melatih guru Taman Kanak-Kanak Anugrah Sayang Ibu di Kampung Jua, Distrik Sungai Limau. Judul pengabdian ini adalah Peluang Wirausaha Baru dalam Kreativitas menguntingan berantai di Anugrah TK Ibu yang Terhormat di Distrik Sungai Limau, Kabupaten Padang Pariaman. Sebelumnya, pelatih tidak melihat bahwa potongan rantai tidak pernah mendapatkan pengetahuan tentang potongan rantai sejauh ini. Oleh karena itu, pelatihan pengembangan kreativitas ini bertujuan untuk menciptakan suatu produk baru, skil dimiliki bisa menjadi suatu usaha yang menjanjikan. Kegiatan pemahaman diberikan dengan metode ceramah, pragaan dan demontrasi, yang akan diajarkan kepada anak-anak TK dan juga untuk bisa menjadi wirausaha bagi para guru untuk bekerja pada seni yang indah. Hasil yang diperoleh dari pengabdian ini, guru tertarik pada denthusiastic. Setelah mendapatkan pelatihan, para peserta diadili oleh anak-anak TK yang mengikuti pelatihan mulai dari berbagai jenis kertas, mengetahui untuk menggabungkan warna-warna benda dengan warna latar belakang, cara menggambar benda yang mereka sukai dan kemudian memotong pada lipatan kertas, mereka sangat senang melakukan kegiatan penyuntingan berantai sebagai peluang wirausaha baru, materi pembelajaran di TK.
\end{abstract}

Kata Kunci: kewirausahaan, kreativitas, memotong.

\begin{abstract}
This service aims to train the teacher of Kindergarten Anugrah Sayang Ibu in Kampung Jua, Sungai Limau District. The title of this dedication is New Entrepreneurial Opportunities in Creativity, chainlinking in the Honorable Mother's Kindergarten Anugrah in Sungai Limau District, Padang Pariaman Regency. Previously, the trainer did not see that chain pieces have never gained knowledge about chain pieces so far. Therefore, this creativity development training aims to create a new product, owned skills can be a promising business. Understanding activities are provided with lecture, demonstration and demonstration methods, which will be taught to kindergarten children and also to become entrepreneurs for teachers to work on beautiful art. The results obtained from this dedication, the teacher is interested in denthusiastic. After getting the training, the participants were tried by kindergarten children who participated in the training, starting from various types of paper, knowing to combine the colors of objects with background colors, how to draw objects they like and then cut on paper folds, they were very happy to do chain editing activities as new entrepreneurial opportunities, learning materials in kindergarten.
\end{abstract}

Keywords: entrepreneurship, creativity, cutting. .

\section{PENDAHULUAN}

Pengabdian ini dilatar belakangi tidak pernah mendapatkan ilmu guntingan berantai selama ini, Sungai Limau merupakan salah satu Taman Kanakkanak Anugrah Sayang ibu terletak di Kampung Jua Kecamatan Sungai limau Kabupaten Padang Pariaman Sumatera Barat. Jarak antara daerah ini dengan ibu kota Kecamatan lebih kurang 57 km, dengan ibu kota administrasi dengan ibu kota Kabupaten Padang Pariaman dan jarak Kota Provinsi Sumatera Barat lebih kurang $67 \mathrm{~km}$.

Pendidikan berlangsung sejak usia dini berlanjut sampai ahkir hayat. Usia dini merupakan periode perkembangan yang sangat penting dalam kehidupan manusia. Pada masa ini seluruh aspek perkembangan 
manusia terbentuk, bukan kecerdasan intelektual saja tetapi seluruh kecakapan psikis, para ahli menamakan preode ini sebagai usia emas perkembangan. Dimana semua kemampuan anak harus dikembangkan sesuai dengan usianya yaitu perkembangan moral dan nila agama, sosial dan kemandisrian, kognitif, bahasa, motorik, dan seni.

Berdasarkan undang-undag nomor 20 tahun 2013 tentang sistem Pendidikan Nasionalpasal 1 ayat 14 bahwa pendidikan anak usia dini merupakan pendidikan yang meberikan layanan pendidikan kepada usia dini pada rentangan usia sejak lahir sampai enam tahun. Para pendidikan harus dapat memberikan layanan secara profesional kepada anak didiknya. Dalam rangka peletakan dasar kearah pengembangan sikap, ilmu pengetahuan dan keterampilan agar anak didik mampu menyesuaikan diri dengan lingkungan serta mempersiapkan diri mereka untuk memasuki pendidikan lanjutan. Pada masa emas ini banyak sekali potensi yang harus dikembangkan potensi tersebut harus difasilitasi dengan baik agar dapat berkembang engan optimal. Salah satu fasilitas yang dapat mengembangkan potensi anak adalah rasa seni. Taman kanak-kanak (TK) merupakan salah satu bentuk pendidikan anak usia dini yang menyelengarakan program pendidikan bagi anak usia dini masa sangat peka yang sangat penting bagi anak yang mampu memfasilitasi anak dalam masa tumbuh kembangnya yaitu pendidikan dan pembelajaran yang sesuai dengan usianya. Kebutuhan dan minat anak. Pendidikan di Taman Kanak-kanak merupakan salah satu bentuk pendidikan yang sangat pennting untuk mengembangkan kepribadian serta mempsiapkan mereka untuk memasuki jenjang pendidikan selanjutnya. Pendidikan Taman-Kanakkanak merupakan jembatan anatara lingkungan keluarga dengan lingkunagan masyarakat yang lebih luas yaitu sekolah dasar dan lingkungan lainnya. Di Taman Kanak-kanak semua aspek perkembangan anak akan dikembangkan dengan baik melalui stimulus-stimulus yang dibutuhkan anak.

Salah satu aspek perkembangan yang dikembangkan di Taman Kanak-kanak adalah aspek rasa seni. Pada dasarnya kemampuan seni menjadi sangat penting dalam meningkatkan perkembangan peserta anak. Pengembang seni perlu dikenalkan kepada anak sejak dini. Oleh karena itu, pendidik dan orang tua dapat mengenalkannya melalui berbagai macam seni yang sederhana atau memelui dengan benda yang ada disekitar lingkungan sekolah yang dapat digunakan untuk melatih anak dalam mengembangkan seni yang dimaksud dengan seni disini adalah seni rupa.
Gorga : Jurnal Seni Rupa

Volume 09 Nomor 01 Januari-Juni 2020

p-ISSN: 2301-5942 | e-ISSN: 2580-2380

Seni rupa terbagi menjdai dua yaitu seni yang berbentuk dua dimensi dan tiga dimensi seni berkaitan herat dengan keindahan, seperti; metode, membentuk, menggambar, mencetak, menempel, dan mengunting , melipat, dalam berbagai kreativitasnya.

Jadi untuk mengembangkan kemampuan seni ruapa pada anak sebaiknya dilakukan melelaui aktivitas yang menyenangkan. Berdasaerkan hasil observasi beberapa di Taman Kanak-kanak masih terlihat bahwa pengembangan anak belum optimal, jadi permasalah yang munccul anatara lain: anak lebih diarahkan pada membaca, menulis dan berhitung. Kurang berkembangn nya kemampuan seni rupa anank seperti: anak kurang kreativitas mengolah bahan untuk menjadi sesuatu, belum berbentuk seni rupa, guru lebih banyak memberikan contoh dipapan tulis. Kurang bervariasinya kegiatan guru untuk mengembangkan kemampuan seni rupa anak di Taman Kanak-kanak . lebih khususnya mengunting berantai belum dilaksanakan di Tamana Kanak-kanak Anugrah Sayang Ibu ini.

Berdasarkan fenomena yang terjadi di lapangan yang diamati pada maka perlu adanya suatu upaya yang dilakukan untuk membantu anak mengembangkan seni rupa adalah salah satunya Peluang Wirausaha Baru Dalam Berkreativitas Mengunting Berantai Di Taman Kanak-Kanak Anugrah Sayang Ibu Pariaman Sumatera Barat. Hal ini untuk mendapatkan guntingan merupakan salah satu kegiatan yang dapat mengembangan kreativitas karena guntingan berantai berhubungan dengan seni rupa kreativitas. Adapaun permasalahan mitra pada Taman Kanak-kanak guru dan anak mempunyai potensial untuk berkreativitas di Kampung Jua sungai limau yang berdasarkan observasi:

Belum dapat mengerti pengolahan dan teknik pembuatan benda seni mengunting sehingga mampu mengembangkan kreativitas.

Belum dapat mengaplikan mengunting berbagai teknik olahan imajinasi dan daya khayal yang terdapat pada belahan otak kanan. Sehingga aktivitas mengunting bagi guru ini tidak hanya menciptakan benda indah juga untuk kebutuhan pembelajaran, namun karya mengunting ini juga indah yang bernilai seni.

Pengabdian yang dilakukan adalah mengunting berantai menjadikan suatu karya seni rupa, mengunting merupakan stimulus yang diberikan nantinya akan menjadikan jari jemari anak akan menjadi lentur, tentag 
seninya anak bisa berimajinasi apa bentuk yang akan dibuatnya sehingga anak kaya dengan imajinasinya. Satu diantara karakteristik anak usia dini adalah anak berimajnasi. Oleh karena itu, pengabdian ini salah satu adalah mengembangkan motorik anak melalui mengunting berantai yang diberikan kepada guru-guru Taman Kanak-kanak. Selanjutnya guntingan berantai ini dilihat di Taman Kanak-kanak ini belum ada dilaksanakan dapat dilihat pada dinding sekolah ini. Dari dua gambar di bawah ini dapat dilihat belum ada hiasan Guntingan berantai pada dinding belum ada.

\section{KAJIAN TEORI}

Peranan pertama guru pengembangan ide dan gagasan dilanjutkan dengan aplikasi, yaitu mempraktekan imajinasi yang dipikirkan. oleh karena itu, peran guru Taman Kanak-kanak sebagai pendidik juga pengembangan kertas yang selama ini digunting hanya dalam bentuk biasa saja. Jadi dengan adanya pelatihan guntingan berantai bagi guru dapat diaplikasikan pada anak agar dapat berkreativitas seni rupa serta mengembangkan motorik halus anak juga mengembangkan kewirausahaan untuk guru dan anak kedepannya serta dapat dihiasai didinding Taman Kanak-kanak menjadi sekolah estetis. Pelatihan yang dicapai melalui kegiatan guna untuk mengembangkan bakat dan bereksperimen sehingga dapat memeunculkan ide dan gagasan imajinasi, kemandirian dan kreativitas anak. Kreativitas itu memberi kesempatan dan kemampuan untuk menyelesaikan maslaah yang individu untuk menciptkan ide-ide asli/adaptif fungsi kegunaannya secara penuh untuk berkembang (Widyatun, 1999)

Senada dengan hal di atas krativitas adalah kemampuan untuk menentukan pertaliahn baru, melihat subjek dari perspektif baru, dan menentukan kombinasi-kombinasi baru dari dua atau konsep yang telah tercetak dalam pikiran (James R. Evan, 1994). Kemudian kereativitas adalah kemampuan berpikir ataupun melakukan tindakan yang bertujuan untuk mencari pemecahan sebuah kondisi ataupun permasalahan secara cerda, berbeda (out of the box), tidak umum orisinil, serta membawa hasil yang tepat dan bermanfaat dalam hal bermanfaat untuk guru, anak untuk bisa namti berwirausaha dengan adanya guntingan berantai.

Inovator kemampuan manusai dalam menggunakan pikiran dan sumber daya yang ada disekelilingnya untuk menghasilkan suatu karya yang benar-benar baru yang orisinil, serta bermanfaat bagi orang banyak. Berdasarkan uraian di atas dapat diambil kesimpulan bahwa, kreatif dan inovatif itu sangatlah diperlukan dalam kehidupan sehari-hari untuk
Gorga : Jurnal Seni Rupa

Volume 09 Nomor 01 Januari-Juni 2020

p-ISSN: 2301-5942 | e-ISSN: 2580-2380

berwira usaha, dituntut untuk memilki jiwa yang kratif inovatif karena keduanya akan menentukan hasil usaha.

Pelatihan mengunting berantai dengan bahan dari kertas dapat meningkatkan kecerdasan dan kreativitas guru, dan ekspresi dalam pengembangan seni rupa bagi anak Taman Kanak-kanak. setiap guru sebaiknya memberi rangsangan terhadap guru mengembangkan kemampuan seni rupa dan kreativitas anak (Rohidi Tjetjep Pohendi, 2015). Tingkat capaian pekembangan terhadap seni rupa dapat dihubungkan pada bidang perkembangan motorik halus anak perlu guru melatih kemampuan memulai melakukan gerakan mengunakan jari-jemari tangan serta pergelangan atangan yang tepat secara terkoordinasi Kemampuan berpikir secara tepat dan teratur dalam berimajinasi anak sehingga menghasilkan suatu karya yang indah penuh perasaan emosional yang menyenangkan dan sebaiknya dibina sedini dari anak Taman Kanak-kanak. Sedangkan kemampuan yang menghasilkan ide dan gagasan perlu dibina dan diarahkan sesuai dengan konteks. Guru sebagai pendidik perlu menyediakan media pembelajaran guna mengembangkan memviasualisasikan dan kreativitas anak akan sangat senang dan suka berimajinasi, selain itu guru juga menyukai kegiatan mewarnai, menggambar, dan mengunting berantai belum ada dilaksanakan, pada hal mengunting berantai dapat membuat anak praktis mengerjakan dengan objek yang sama.

\section{METODE PENELITIAN}

Metode yang dilakukan dalam kegiatan ini yakninya pendekatan yang dilakukan secara langsung ataupun tidak langsung, yaitu terlebih dahulu melakukan Focus Group Discussion (FDG) dengan mitra, melaksanakan kegiatan awal, melaksanakan kegiatan inti, dan diakhir kegiatan melakukan evaluasi sejauh mana capaian dari kegiatan pengabdian kepada masyarakat ini.

\section{HASIL DAN PEMBAHASAN \\ 1.Hasil}

\section{1). Kegiatan 1}

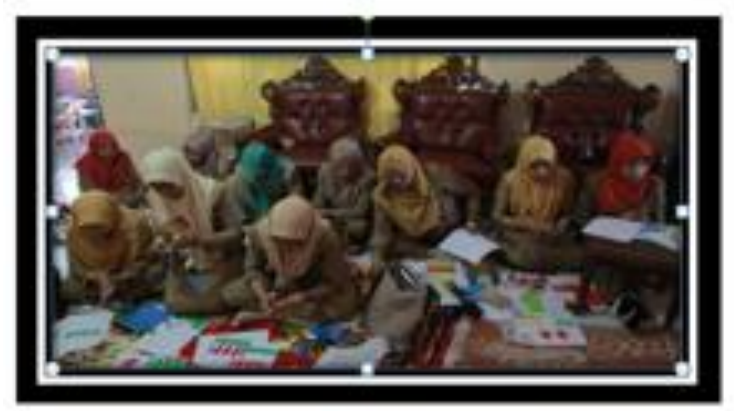

Gambar 1. Kegiatan Menggunting Brantai (Sumber: Farida Mayar, 2019) 


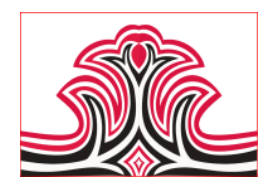

2). Kegiatan 2

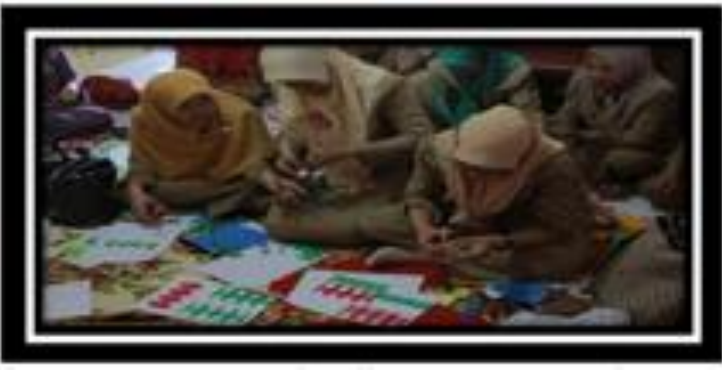

Gambar 2. Kegiatan Menggunting

(Sumber: Farida Mayar, 2019)

\section{3). Kegiatan 3}

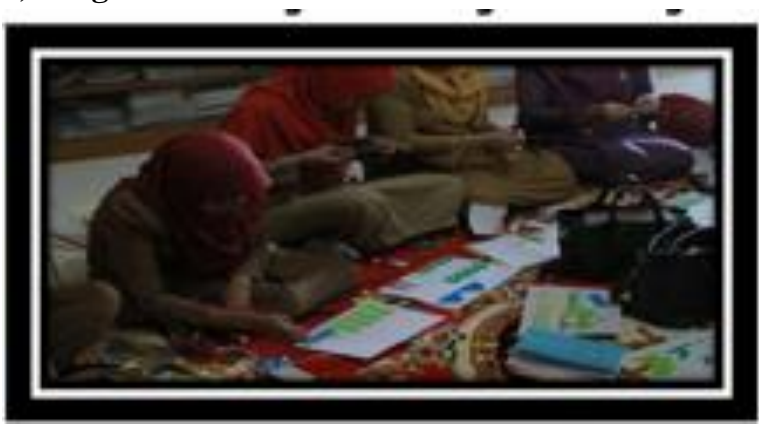

Gambar 3. Penempelan Hasil Karya (Sumber: Farida Mayar, 2019)

\section{4). Karya 1}

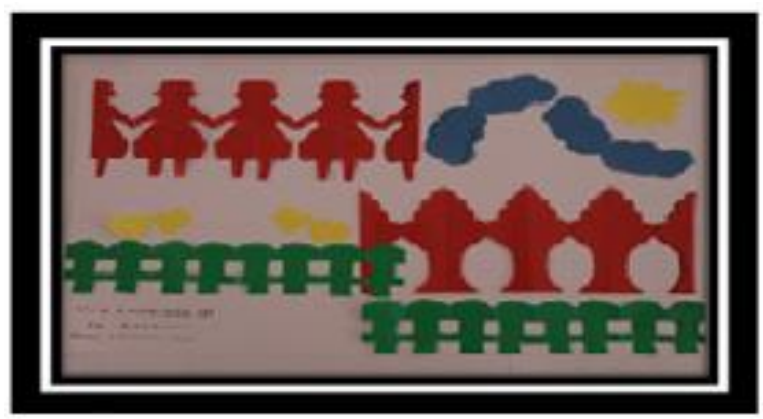

Gambar 4. Hasil Karya Gunting Brantai (Sumber: Farida Mayar, 2019)

\section{Pembahasan}

Peserta pelatihan pengabdian kepada masyarakat berjumlah sebanyak 16 orang yang terdiri dari kepala dan guru sekolah Taman Kanak-kanak se Kecamatan Sungai Limau Padang Pariaman Hasil dari pelatihan pada tahap pertama nara sumber memberikan penjelasan dengan power poin, guru praktek membuat secara mendasar dahulu yaitu mengunting bentuk geometris seperti lingkaran dan bentuk oval dengan kertas origami berwarna yang landasan kertas warna putih, hasil yang didapat bagus dalam penguntingannya, tetapi menempelkan pada kertas belum bisa menyusun penguntingannya secara komposisi dalam unsur-unsur seni.
Gorga : Jurnal Seni Rupa

Volume 09 Nomor 01 Januari-Juni 2020 p-ISSN: 2301-5942 | e-ISSN: 2580-2380

Tahap kedua, Narasumber memberikan tugas lagi dengan bentuk bebas tetapi dalam kajian kurikulum Anak Usia Dini yang ada pada tema. Kemudian hasilnya diapreasiasi guna menghargai karya perserta tersebut. Pelatihan hari kedua narasumber memberikan pelatihan guntingan berantai dalam bentuk tema yang dan menjadi suatu cerita kepada anak anatinya. Ada yang membuat tema lingkungan sekolah. Yang terdiri objek tersebut dimulai dari pagar, pohon, rumput, bunga, anak-anak TK yang sedang bergandengan, ada rumah sekolah. Sesuai dengan tujuan pengabdian kepada masyarakat khususnya Taman Kanak-kanak Anugrah Sayang Ibu, yaitu untuk membantu guru-guru TK agar dapat: (1) memahami prinsip dan proses disain untuk dikembangan diaplikasikan pada kertas yang berbagai bentuk sesuai dengan imajinasi peserta, dihubungkan dengan tema yang ada di Taman kanakkanak, sehingga desain gambarnya menjadi bervasiasi, (2) mengembangkan disain gambar pada lipatan kertas yang berlapis (3) mengembangkan keterampilan pengerjaan mengunting kertas yang berlapis.

Tiga tujuan ini saling terkait, tujuan butir yang pertama merupakan pemahaman terhadap proses dan persyaratan pembuatan dan penngembangan disain, sedangkan butir tujuan yang kedua merupakan aplikasi pemahaman menjadi produk yang bernilai ekonomis dari tujuan pada butir pertama. Tujuan ini dapat dicapai dengan baik, dalam segi pemahaman guru-guru TK telah dapat memahami pengertian dan prinsip mengunting. Kemudian bahan dan alat yang dipergunakan.

Adapun secara teori nara sumber menjelaskan secara awal dengan teori yaitu UU No 20 th 2003. Sistem pendidikan Nasional pasal 1 ayat 14 bahwa Pendidikan Anak Usia Dini (PAUD) merupakan pendidikan yang memberikan layanan pendidikan kepada usia dini berusia 0-6 tahun. Pendidik harus dapat memberikan layanan secara profesional kepada Anak Usia Dini (AUD) dalam rangka peletakan dasar kearah pengembangan sikap, pengetahuan, dan keterampilan, harus bisa penyesuaian diri dengan lingkungan. Pengembangan AUD: nilai agama, sosial, emosional, bahasa, kognitif, motorik, dan seni. Salah satu aspek perkembangan yang harus dikembangkan di Taman Kanak-kanak (TK) adalah aspek seni, yaitu seni rupa. Seni rupa terbagi dua dimensi, dan tiga dimensi yang berkaitan herat dengan keindahan: menggambar, mencetak, meronce, membentuk, melipat, menempel, mengunting dalam berbagai kreativitas. Untuk membangun kemampuan seni rupa aktivitas yang menyenangkan. untuk mengembangkan kreatifitas 
guru Taman Kanak-kanak dengan seni mengunting berantai.

Bertujuan 1) Untuk mengaplikasikan mengunting berantai berbagai olahan imajinasi dan daya khayal pada belahan otak kanan. 2) untuk dapat mengembangan motorik Halus anak. 3) Untuk kebutuhan pembelajaran karya mengunting berantai indah dan bernilai seni. 4) Untuk dapat berwirausaha. 5) Untuk dapat mengembangkan kreativitas anak karena menguntingan berantai berhubungan dengan seni rupa dan kreativitas.

Narasumber menjelaskan bahwa, a) kertas origami ini berbentuk segi empat kubus yang tertera pada papan tulis, b) kertas origami di lipat dua, c) kertas origami digunting menjadi dua bagian, d) kertas origami yang bagian satu di ambil kemudian dilipat menjadi empat lipatan, e) buat gambar disain sesuai dengan tema dengan pensil, f) kemudian gunting, g) lipatan kertas yang telah dibuat gambar lalu gunting dan tinggalkan bahagian tertentu, supaya tidak terputus, h) buka lipat kertas dan lihat hasilnya.

Awal mengunting pelatih mengajarkan cara melipat kertas dengan model pola dasar, seperti motif oval, kemudian berangsur-angsur dipanjangkan menjadi pohon, selanjutnya dikembangkan menjadi motif manusia yaitu anak-anak dan mereka masing-masing bervariasi bentuk yang dibuatnya sesuai dengan keinginannya.

\section{KESIMPULA DAN SARAN}

\section{Kesimpulan}

Berangkat dari fakta pengabdian masyarakat dapat melahirkan karya-karya bernuangsa baru seperti mengunting berantai pada Taman Kanak-kanak Kecamatan Sungai Limau Padang Pariaman. Sebelumnya pembelajaran bahan kertas yang banyak digunakan di Taman Kanak-kanak yakni untuk melipat, dan menempel saja. Pembelajaran mengunting berantai ini dapat mengembangkan kreativitas anak dan guru di Taman Kanak-kanak.

Perencanaan bahan kertas di disain dengan pensil lalu dilipat dan mengandakan lipatan, lalu digunting, pada saat mengunting ditingalkan sebagian kertas tidak terputus, kegunaannya untuk supaya kertas tidak terpisah satu dengan objek yang lainnya. Setelah selesai mengunting tinggal objeknya. Setelah mendapat pelatihan guru-guru mencobakan kepada anak didiknya di Taman Kanak-kanak mengajar. Peserta yang ikut pelatihan mulai dari pengenalan materi macam-macam kertas, dan memadukan warna objek dengan warna
Gorga : Jurnal Seni Rupa

Volume 09 Nomor 01 Januari-Juni 2020

p-ISSN: 2301-5942 | e-ISSN: 2580-2380

latar belakang, cara mengambar objek yang mereka sukai kemudian digunting di atas lipatan kertas. Peserta pelatihan sangat antusias melakukan kegiatan mengunting berantai sebagai materi bahan pembelajaran di Taman Kanak-kanak.

\section{Saran}

Pelatihan karya seni gunting berantai, yang di berikan kepada peserta pelatihan dapat dikembangkan di tempat mereka bertugas. Penulis berharap khususnya kepada mahasiswa jurusan PGPAUD agar mampu menciptakan karya-karya mengunting dan mewarna serta melipat demi keterampilan. Mengunting dan mewarna serta melipat merupakan identitas diri guru PAUD yang sudah diturunkan dari generasi ke generasi anak didiknya. Banyak hal yang bisa di eksplorasi dari mengunting dan mewarna serta melipat untuk dapat menciptakan karya seni baru yang lebih bagus, bermutu dan mampu bersaing dengan teknologi modern lainnya.

\section{DAFTAR RUJUKAN}

Chandra Mohanty, Bijo. (2018). Natural Dyeing Prosses Of India. India: Sarabhai Foundation.

Evans, James R. (1994). Berpikir Kreatif, dalam Pengambilan Keputusan dan Manajemen. Jakarta: Bumi Aksara

Pujianti, Yuli. (2012). Mengembangkan Konsep Diri Melalui Bermain Peran Jurnal Pendidikan Anak Usia Dini, 06(02),

Rohidi Tjetjep Pohendi. (2015). Ekspresi Seni Orang Misikin. Bandung: Nuansa Yayasan.

Widayatun, T. R. (1999). Ilmu Prilaku. Jakarta: CV. Sagung Seto. 